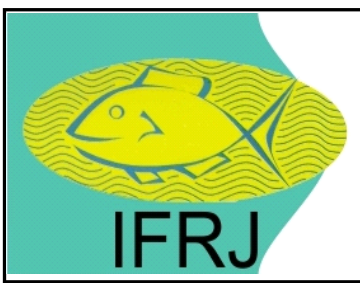

Available online at: http://ejournal-balitbang.kkp.go.id/index.php/ifrj

e-mail:ifrj.puslitbangkan@gmail.com

INDONESIAN FISHERIES RESEARCHJOURNAL

Volume 26 Nomor 2 December 2020

p-ISSN: 0853-8980

e-ISSN: 2502-6569

Accreditation Number RISTEK-BRIN: 85/M/KPT/2020

\title{
COMMUNITY STRUCTURE AND TROPHIC STATUS OF REEF FISH IN NATUNA WATERS
}

\author{
Isa Nagib Edrus ${ }^{\star 1}$ and Pratiwi Lestari ${ }^{1}$ \\ ${ }^{1}$ Researcher in Research Institute for Marine Fisheries, Jl. Raya Bogor No.507, Nanggewer Mekar, Cibinong, Bogor, West Java \\ Received; September 08-2019 Received in revised from April 29-2020; Accepted May 18-2020
}

\begin{abstract}
A field research on reef fish-community structures in Natuna waters was carried out in November 2015. This research aimed to obtain the trophic composition of reef fishes and its correlation to diversity, density, and biomass. Underwater visual census on several transect areas was used to collect data. Results show that the identified reef fishes were about 100 species of target-reef fish belonging to 18 families and 23 species of indicator-reef fish of the Chaetodontidae family. The mean species number of target reef fish and indicator reef fish were 42 and 7 species, respectively. The mean density of the target reef fish and indicator reef fish were 0.4 and 0.05 individual per $\mathrm{m}^{2}$, respectively. The mean of the reef fish relative stock was $0.6 \mathrm{ton} / \mathrm{ha}$. The composition of the herbivores mostly found in the resilient coral reefs $r$ was $46.45 \%$ and the omnivores and planktivores as marketable targeted fishes were $18.64 \%$ and $14.28 \%$, respectively. The most predominant or major families were from herbivorous, carnivorous, planktivorous, and corallivorous fishes, including Scaridae (i.e. Scarus spp), Lutjanidae (i.e. Lutjanus spp.), Caesionidae (i,e. Caesio cuning and Pterocaesio caerulaurea), and Chaetodontidae (i.e. Chaetodon baronessa and Chaetodon octofasciatus). The results suggested that the community structures were quite prospectively implemented for fisheries; however, it may not be promising for coral resilience. Furthermore, the coral health status was at moderate level in regard to the high numbers of corallivorous butterflyfishes.
\end{abstract}

\section{Keywords: Reef fishes; structure community; biomass INTRODUCTION}

The Natuna Islands are administratively included in the Natuna Regency and part of the Riau Islands Province that is surrounded by wonderful coral reef waters. Physically, Natuna waters are under control of the Republic of Indonesia's Authority and also as a part of the Economic Exclusive Zone. From the national fishery policy view, Natuna waters is described as Fishery Management Area 711, bordering the South China Sea. The Natuna coral reef areas are potential spawning and nursery grounds for the high economical-valuable fisheries of both ornamental and edible reef fishes (COREMAP, 2007). However, the areas are vulnerably exposed to illegal fishing for a long time due to coral reef associated fisheries.

Escalating fisheries with poor environmental protected management for many years (Pet-Soede \& Erdmann, 1998; Pauly et al., 1989) as well as cyanide and blast fishing have been making serious damages to coral reefs in Indonesia throughout the time (Edinger et al., 1998; Pet-Saode et al., 2000). The strongest reef fish affinity to coral reef is critical for habitat needs and the destructive fishing may be a threat to fish for living (Jones et al., 2004; Gratwicke \& Speight. (2005). The undeniable fact that surrounds damages due to overfishing results in negative impact on fish resources in some regions of the provinces (Anonymous, 2011), particularly huge dwindling fish production came about within the regions was typically addressed to the habitat damaging and overfishing (Fauzi, 2005). Further impacts, each positive and negative manners, conjointly might happen in fish communities to preserve the functional purposes, particularly for herbivore fishes as a grazer group. The grazers have a considerable-essential role in coral reef resilience. Fishery activities may be an indirect controlling factor in composition shifting of the functional groups of fishes, mainly the structure balances among herbivores and carnivores (Berkepile \& Hay, 2008 ; Green \& Bellwood, 2009).

One of the most important challenges for policy decision making about the Natuna coral reef management is to describe and explain the health of 
coral reefs in terms of geographical patterns in diversity of reef fishes. Fish community structures, as well as percent coral covers, are suitable quality indicators for coral reef health assessment. They are used as substantial parameters to precisely assess the damage of coral reefs (Wilson \& Green, 2009). Therefore, certain reef fish have the best habitual response to environmental changes in their favorable and suitable habitat and preferred feed. For this reason, some researcher often use the corallivorous fish group to generally define the damage of coral reefs (Crosby \& Reese, 1996). Some "grazers" of herbivorous fishes are also habitually used in analyzing the roles of grazers in terms of resilience processes in a coral reef ecosystem. Carnivore fish groups, as well as some species of potential targeted fishes in fisheries, like groupers, snappers, and sweaplips, are a typical functional group of fishes used to assess population size growth of other functional groups in coral reef areas. Growing population of the carnivorous fish group may reduce the herbivorous fish group; however, fishery activities can reduce the population of all fish fungsional groups (Halford et al., 2004 ; Obura \& Grimsditch, 2009).

Some indicators are actually warnings for policy decision making; however, those have not likely been considered yet by local government unit operators. As presumed that if tremendous damage of resources were taking place in the region, evaluation and monitoring activities may be late to carry for. Fish functional groups (economical value species) are a serious implication for the reef fish community structures, whereas environmental governance needs them. It's important to know the composition of functional fishes in the Natuna coral reefs. Coral reef management is likely insufficient information that is substantial to know how the critical support of reef fishes to coral reefs and the crucial threat of fisheries to coral reef resources (Salm \& Kenchington, 1988).

Reef fish community structure patterns might be an interesting analysis that provides insight into monitoring coral reef degradation and supports sustainable uses of the coral reef resources (Salm \& Kenchington, 1988). The analysis is likely close to a prerequisite for fishing management prioritization. Reef fish potency can be measured using the stock method, for which annual fishing data are prepared. Such data are rarely derived from nearby areas of coral reefs; however, those are mostly generated from offshore fishing areas. Actually, recorded demersal fish data didn't return from fishing mistreatment habitual fishing gears applying in reefs, however using special gears applying for demersal purposes. Hence, the data analysis does not focus on the intrinsic data to coral reef characteristics. On the other hand, reef fish data and information may be directly gathered from the genuine coral reef ecosystem by divers to find shortly time out primarily data, from which diversity, density, biomass, relative stock, and species composition can be analyzed. Guidelines on the study of reef fish health assessment have been prepared by Giyanto et al. (2014) to provide the COREMAP-CTI-monitoring needs for national coral reef health studies. However, it appears very little research has been focused on the structures of coral reef communities in the coral reefs of Natuna, while fishing stresses known to occur there seems to be highlighting the problems of fishery management.

This study aimed to obtain the variable data of diversity, density, biomass, and fish composition of fish functional groups in terms of herbivorous, carnivorous, omnivorous, and corallivorous fishes. It's essential to look forward to the management of potential marketable fishes in fisheries, supportable fishes in coral resilience, and suitable indicator fishes in coral reef health monitoring.

\section{MATERIALS AND METHODS}

Field observation was carried out in November 2015 at the waters of the Natuna Islands, Riau Islands Province. The study sites consisted of 14 geographical positions in the areas illustrated in Figure 1 and listed in Table 1. 


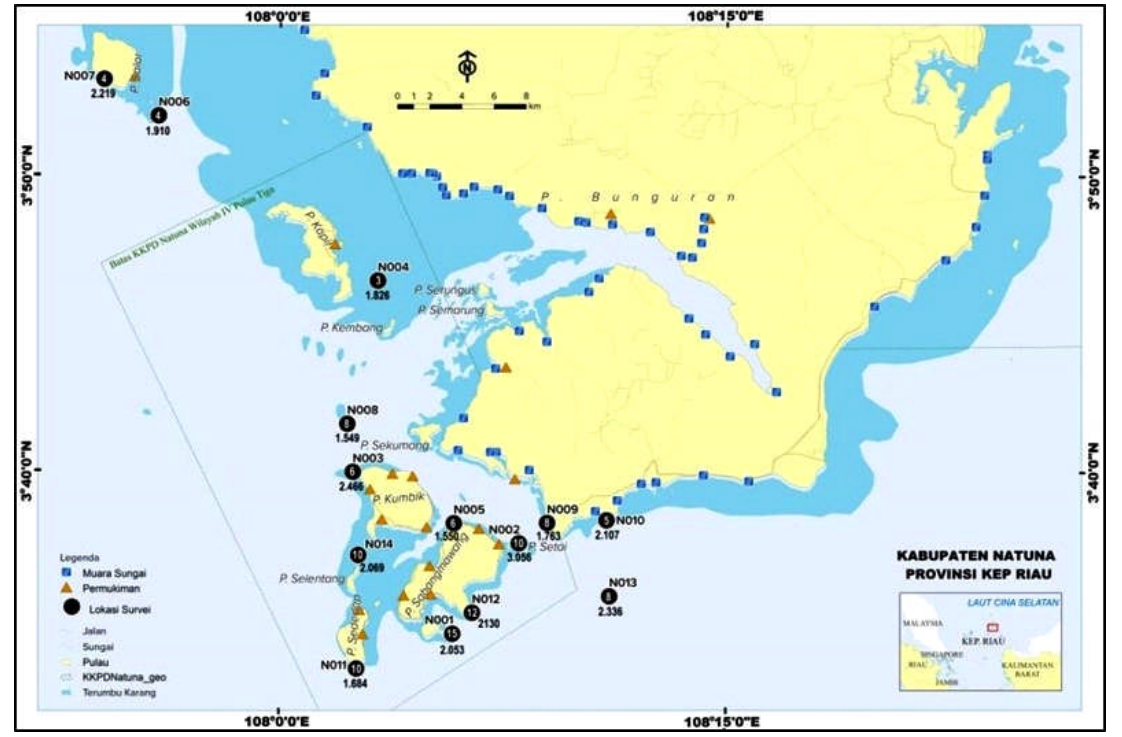

Figure 1. A map showing the study sites in reef waters of Natuna Island.

Table 1. Station codes, names, geographical positions and other remarks of the study sites

\begin{tabular}{|c|c|c|c|c|c|c|}
\hline \multirow[b]{2}{*}{$\begin{array}{c}\text { Transect } \\
\text { Codes }\end{array}$} & \multirow[b]{2}{*}{$\begin{array}{l}\text { Location } \\
\text { Names }\end{array}$} & \multirow{2}{*}{\multicolumn{2}{|c|}{$\begin{array}{c}\text { Geographical } \\
\text { Positions }\end{array}$}} & \multicolumn{3}{|c|}{ Census Areas $\left(\mathrm{m}^{2}\right)$} \\
\hline & & & & $\begin{array}{l}\text { Free } \\
\text { Trans. }\end{array}$ & $\begin{array}{l}\text { Belt } \\
\text { Trans. }\end{array}$ & $\begin{array}{l}\text { Total } \\
\text { Areas }\end{array}$ \\
\hline N001 & Serantas Island & $3^{\circ} 34.5038^{\prime}$ & $108^{\circ} 05.8247^{\prime}$ & 803 & 1,250 & 2,053 \\
\hline N002 & Setai Island & $3^{\circ} 37.5662^{\prime}$ & $108^{\circ} 08.0482^{\prime}$ & 1,806 & 1,250 & 3,056 \\
\hline N003 & Kumbik Island & $3^{\circ} 39.9653^{\prime}$ & $108^{\circ} 02.4717^{\prime}$ & 1,216 & 1,250 & 2,466 \\
\hline N004 & Kembang Island & $3^{\circ} 46.4282^{\prime}$ & $108^{\circ} 03.2980^{\prime}$ & 576 & 1,250 & 1,826 \\
\hline N005 & Sabangmawang Island & $3^{\circ} 38.2370^{\prime}$ & $108^{\circ} 05.8655^{\prime}$ & 300 & 1,250 & 1,550 \\
\hline N006 & Kukop & $3^{\circ} 51.9918^{\prime}$ & $107^{\circ} 55.9258^{\prime}$ & 660 & 1,250 & 1,910 \\
\hline N007 & Solor Island & $3^{\circ} 53.2237^{\prime}$ & $107^{\circ} 54.0990^{\prime}$ & 969 & 1,250 & 2,219 \\
\hline N008 & Burung Island & $3^{\circ} 41.5895^{\prime}$ & $108^{\circ} 02.2822^{\prime}$ & 299 & 1,250 & 1,549 \\
\hline N009 & Tanjung Tekul & $3^{\circ} 38.2540^{\prime}$ & $108^{\circ} 08.9935^{\prime}$ & 513 & 1,250 & 1,763 \\
\hline N010 & Setukul & $3^{\circ} 38.3542^{\prime}$ & $108^{\circ} 10.9892^{\prime}$ & 857 & 1,250 & 2,107 \\
\hline N011 & Sededap Island & $3^{\circ} 33.3135^{\prime}$ & $108^{\circ} 02.6047^{\prime}$ & 434 & 1,250 & 1,684 \\
\hline N012 & Semasin Island & $3^{\circ} 35.2137^{\prime}$ & $108^{\circ} 06.4835^{\prime}$ & 880 & 1,250 & 2,130 \\
\hline N013 & Tekul Path Reef & $3^{\circ} 35.7812^{\prime}$ & $108^{\circ} 11.0825^{\prime}$ & 1,086 & 1,250 & 2,336 \\
\hline N014 & Buluh Island & $3^{\circ} 37.1563^{\prime}$ & $108^{\circ} 02.6632^{\prime}$ & 819 & 1,250 & 2,069 \\
\hline
\end{tabular}

The method used for data gathering was standard underwater visual census (UVC) of fish, focusing on functional fish groups, such as herbivores, carnivores, omnivores and corallivores, especially for the fish species of marketable fish groups, grazer fish groups, and indicator fish groups (English et al., 1994; Giyanto et al., 2014). Before the study sites were decided, a Manta Tow survey was conducted to find approximately more than $50 \%$ coral coverage sites that were appropriate for underwater visual census (English et al., 1994).

Data collection at each study site was conducted using SCUBA by a scientific diver with a buddy (a diving partner as international diving rules) at five points that have $50 \mathrm{~m}$ long transect lines lay at the coral reef area. The distance between transect line points was approximately $50 \mathrm{~m}$, parallel to the shore line of the island. While observing at each transect, the divers waited about 15 minutes after laying the transect before counting, to allow fishes to resume normal behaviour to settle before starting recording. The observers or divers swam slowly along the transect and recorded the fish encountered within approximately 2,5 meters on both sides (left and right side from the transect line). For each species at each transect, the total number of individuals and their body lengths were recorded. The species identification used a pictorial book guidance (Kuiter \& Tonozuka, 2001; Allen \& Erdmann, 2012). The assumption of body length used the stick method to obtain the relative size of fish total length, particularly for the five centimeter interval length of 6 to 1011 to 15,16 to 20,21 to 25,26 to 30,31 to 35 , etc. 
The data analyses customarily emphasized on (1) reef fish species listed in taxonomic group and their species number in respective transects (Giyanto et al., 2014); (2) density calculation of individual number per transect area given in respective transects (Giyanto et al., 2014); (3) biomass calculation of the length-weight correlation formula for respective transects (Wilson \& Green, 2009); (4) reef fish relative stock calculation of value conversion of the biomass per hectare in respective transect sites (Giyanto et al., 2014). The formulas used to approach those aims above were as follows.

Mean of Density (individual $\left./ m^{2}\right)=\frac{I N(T)}{T A(T)}$

where :

IN = Individual Number

$T=$ Transect Site

$T A=$ Total Area in $\mathrm{m}^{2}$

$W=a \times L^{b}$

where:

$W \quad=$ Body Weight $(\mathrm{gr})$

$L \quad=$ Total Length $(\mathrm{cm})$

$a$ and $b=$ constant variables, given in Fishbase Web

(Froese \& Pauly (2014). $\begin{aligned} & \text { Mean of } \\ & \text { Biomass }\left(\mathrm{g} / \mathrm{m}^{2}\right)\end{aligned}=\frac{\begin{array}{l}\text { Gram Biomass of all Fishes in } \\ \text { the Respective Site Transects }\end{array}}{\begin{array}{l}\text { Total Square Meter Areas } \\ \text { in Respective Site Transects }\end{array}}$

$\begin{aligned} & \text { Relative Fish } \\ & \text { Stock (ton/ha) }\end{aligned}=\frac{\text { Mean Biomass }\left(\mathrm{gram} / \mathrm{m}^{2}\right)}{1,000,000(\mathrm{gram})} \times 10,000$

\section{RESULTS AND DISCUSSION \\ Results}

\section{Diversity and Density}

All data analyses were shown in Table 2. From 18 families that were found in all study sites, 100 species of them were the target fishes and 23 species were indicator species especially from family Chaetodontidae. They were varied in species number as well as in individual densities and biomass relative stocks among the study sites. The lowest species number were 25 species recorded in Kembang Island (N004) and its contrary were 55 species recorded in Sededap Island (N011). The calculation of the data variation presented $836 \pm 235$ (Mean \pm SD) for individual numbers and 0.4 individual per $\mathrm{m}^{2}$ for density. The density was equivalent to 4,153 individuals per hectare.

Table 2. Individual numbers, species numbers, density, and its relative stock of reef fishes

\begin{tabular}{clcccc}
\hline $\begin{array}{c}\text { Transect } \\
\text { Codes }\end{array}$ & \multicolumn{1}{c}{$\begin{array}{c}\text { Location } \\
\text { Names }\end{array}$} & $\begin{array}{c}\text { Ind. } \\
\text { No. }\end{array}$ & $\begin{array}{c}\text { Species } \\
\text { No. }\end{array}$ & $\begin{array}{c}\text { Density/m } \\
(\ddot{x})\end{array}$ & Ind. Stock/ha. \\
\hline N001 & Serantas Island & 599 & 41 & 0.3 & 2,981 \\
N002 & Setai Is. & 843 & 42 & 0.3 & 2,759 \\
N003 & Kumbik Is. & 704 & 39 & 0.3 & 2,855 \\
N004 & Kembang Is. & 652 & 25 & 0.4 & 3,571 \\
N005 & Sabangmawang Is. & 611 & 33 & 0.4 & 3,942 \\
N006 & Kukop & 741 & 48 & 0.4 & 3,880 \\
N007 & Solor Isl. & 530 & 31 & 0.2 & 2,388 \\
N008 & Burung Is. & 495 & 35 & 0.3 & 3,196 \\
N009 & Tanjung Tekul & 1171 & 49 & 0.7 & 6,642 \\
N010 & Setukul & 746 & 44 & 0.4 & 3,541 \\
N011 & Sededap Is. & 1042 & 55 & 0.6 & 6,188 \\
N012 & Semasin Isl. & 1304 & 52 & 0.6 & 6,122 \\
N013 & Tekul Path Reef & 1466 & 47 & 0.6 & 6,26 \\
N014 & Buluh Island & 800 & 42 & 0.4 & 3,867 \\
\hline
\end{tabular}

\section{Species Composition}

Species with the highest individual number in Natuna coral reefs was Scarus ghobban $(18.64 \%)$ of family Scaridae, followed by Caesio cuning $(14,28 \%)$ of family Caesionidae (Appendix 1). Furthermore, the top biomass rank of reef fish species were Caesio cuning $(15.2 \%)$, followed by Caesio caerulaurea (12 $\%)$ and Scarus ghobban (10.5\%) (Appendix 2). The schooling of Scarus ghobban was mostly recognized in the juvenile phases; for this reason, the highest individual number of Scarus ghobban (in Table 2) did not affect on valuing their biomass; instead, Caesio cuning had the highest total biomass.

The fifteen major fish populations, with regard to total individuals, consisted of parrotfishes, fusiliers, and snappers, were Scarus ghobban, Caesio cuning, Caesio caerulaurea, Scarus hypselopterus, Chlorurus sordidus, Pterocaesio tessellata, Scarus niger, 
Scolopsis ciliatus, Ctenochaetus striatus, Lutjanus ehrenbergii, Lutjanus biguttatus, Pterocaesio digramma, Lutjanus decussatus, Siganus virgatus, dan Lutjanus vitta (Appendix 1).

Furthermore, the top fifteen of largest biomass were Caesio cuning, Caesio caerulaurea, Scarus ghobban, Chlorurus sordidus, Naso lituratus, Scarus niger, Pterocaesio tessellata, Ctenochaetus striatus, Lutjanus decussatus, Scarus hypselopterus, Pterocaesio digramma, Scarus flavipectoralis, Lutjanus biguttatus, Lutjanus vitta, and Caesio lunaris (Appendix 2). These species were classified as the families of parrotfishes (Scaridae), fusiliers (Caesionidae), snappers (Lutjanidae), and surgeonfishes (Acanthuridae).

The composition of fish functional groups based on their feeding behaviour were herbivores (46.45\%), carnivores $(22.97 \%)$, and planktivores $(30.71 \%)$ (Appendix 1). Mostly, herbivorous fishes were parrotfishes (Scaridae), whereas carnivorous fishes were mostly snappers (Lutjanidae) and the most planktivorous fishes were fusiliers (Caesionidae). Mainly, the functional groups of fish communities occupied the study sites -predominantly referred to the herbivore group, including grazers, that has been habitually well known as supporting resilience processes in coral reef ecosystems.

\section{Biomass and Relative Stocks}

Biomass calculation by separately interposing the body total length of fishes to the second formula created some individuals biomass information of all fish species with success known once the survey was conducted. The total biomass, referred to the sum of individual biomass of all fishes in each site of the study areas, was shown in Table 3.-The site with the highest biomass (332 kg) was Tekul Path Reef (N013), followed by Semasin Island (N012) with227 kg. The biomass between $100 \mathrm{~kg}$ and $200 \mathrm{~kg}$ were represented in some sites, i.e. Sededap Island (N011), Tanjung Tekul (N009), Kukop (N006), and Serantas Island (N001), while the rest had biomass less than $100 \mathrm{~kg}$.

Biomass data, resulted by this method, often represents the only information available for the small scale measures of some local transects, but not for the general areas given in regional study areas. For this reason, relative stock is an important variable in fishery management as it provides a basis for predicting the adequately size recruitment in terms of harvesting management purposes. Biomass conversion into relative stock of reef fishes in the respective study areas (Table 3 ) showed the differences in availability of fish stocks resources, from high to low stocks, such as in Tekul Path Reef (1.4 ton/ha), Semasin Island (1.1 ton/ha), Sededap Island (1 ton/ha), and Tanjung Tekul (0.9 ton/ha). Furthermore, the average of reef fish relative stock, estimated from samples of 14 study sites, was $0.6 \pm$ $0.29($ Mean \pm SD) ton/ha.

Table 3. Biomass and stock of reef fishes in Natuna coral reefs

\begin{tabular}{clcccc}
\hline $\begin{array}{c}\text { Transect } \\
\text { Code }\end{array}$ & \multicolumn{1}{c}{ Location } & $\begin{array}{c}\text { Total } \\
\text { Biomass } \\
(\mathbf{k g})\end{array}$ & $\begin{array}{c}\text { Survey } \\
\text { Area } \\
\left(\boldsymbol{m}^{2}\right)\end{array}$ & $\begin{array}{c}\text { Biomass } \\
\text { Mean } \\
\left(\mathbf{g r a m} / \mathbf{m}^{2}\right)\end{array}$ & $\begin{array}{c}\text { Relative } \\
\text { Stock } \\
\text { (ton/ha. })\end{array}$ \\
\hline N001 & Serantas Is. & 102 & 2,053 & 50 & 0,5 \\
N002 & Setai Is. & 98 & 3.056 & 32 & 0.3 \\
N003 & Kumbik Is. & 79 & 2,466 & 32 & 0.3 \\
N004 & Kembang Is. & 46 & 1,826 & 25 & 0.3 \\
N005 & Sabangmawang Is. & 70 & 1,550 & 46 & 0.5 \\
N006 & Kukop & 208 & 1,910 & 57 & 0.6 \\
N007 & Solor Is. & 58 & 2.219 & 26 & 0.3 \\
N008 & Burung Is. & 58 & 1,549 & 37 & 0.4 \\
N009 & Tanjung Tekul & 162 & 1,763 & 92 & 0.9 \\
N010 & Setukul & 86 & 2.107 & 41 & 0.4 \\
N011 & Sededap Is. & 170 & 1,684 & 101 & 1.0 \\
N012 & Semasin Is. & 227 & 2,130 & 107 & 1.1 \\
N013 & Tekul Path Reef & 332 & 2,336 & 142 & 1.4 \\
N014 & Buluh Is. & 94 & 2,069 & 43 & 0.5 \\
\hline
\end{tabular}




\section{Diversity of Indicator Fishes}

Several species of indicator fishes were well known as the indicator of coral reef health conditions, includeing corallivorous fishes of the functional fish groups. Most of them were taxonomically classified in the familyChaetodontidae (butterflyfishes), some of Scaridae (parrotfishes), and some of Acanthuridae (surgeonfishes). There were 23 species of butterflyfishes (Chaetodontidae) successfully recorded in all sites of the study areas. The sites with a quite high species number of butterflyfishes included Buluh Island (N014), Tekul
Path Reef (N013), and Burung Island (N008). Furthermore, the sites with higher individual numbers were Tekul Path Reef (N013), Kumbik Island (N003), Kukop (N006), Sededap Island (N011), and Buluh Island (N014), shown in Table 4.

Butterflyfish composition of the total individuals is presented in Figure 2. The five major corallivorous species based on total individuals recorded are Chaetodon baronessa, Chaetodon octofasciatus, Heniochus varius, Chaetodon trifasciatus, and Chaetodon adiergastos.

Table 4. Variation of individual and species numbers of Butterflyfishes

\begin{tabular}{|c|c|c|c|c|c|c|c|c|c|c|c|c|}
\hline \multirow{3}{*}{$\begin{array}{l}\text { Descriptior } \\
\text { Individual } \\
\text { Number }\end{array}$} & \multicolumn{12}{|c|}{ STUDY SITES } \\
\hline & N001 & N002 & N003 & N004 & N005 N006 & N007 & N008 & N009 & N010 & N011 & N012 & N013 N014 \\
\hline & 16 & 34 & 74 & 12 & 66 & 21 & 53 & 35 & 51 & 57 & 13 & 57 \\
\hline $\begin{array}{l}\text { Species } \\
\text { Number }\end{array}$ & 6 & 7 & 7 & 5 & 5 & 3 & 10 & 9 & 7 & 9 & 6 & 11 \\
\hline
\end{tabular}

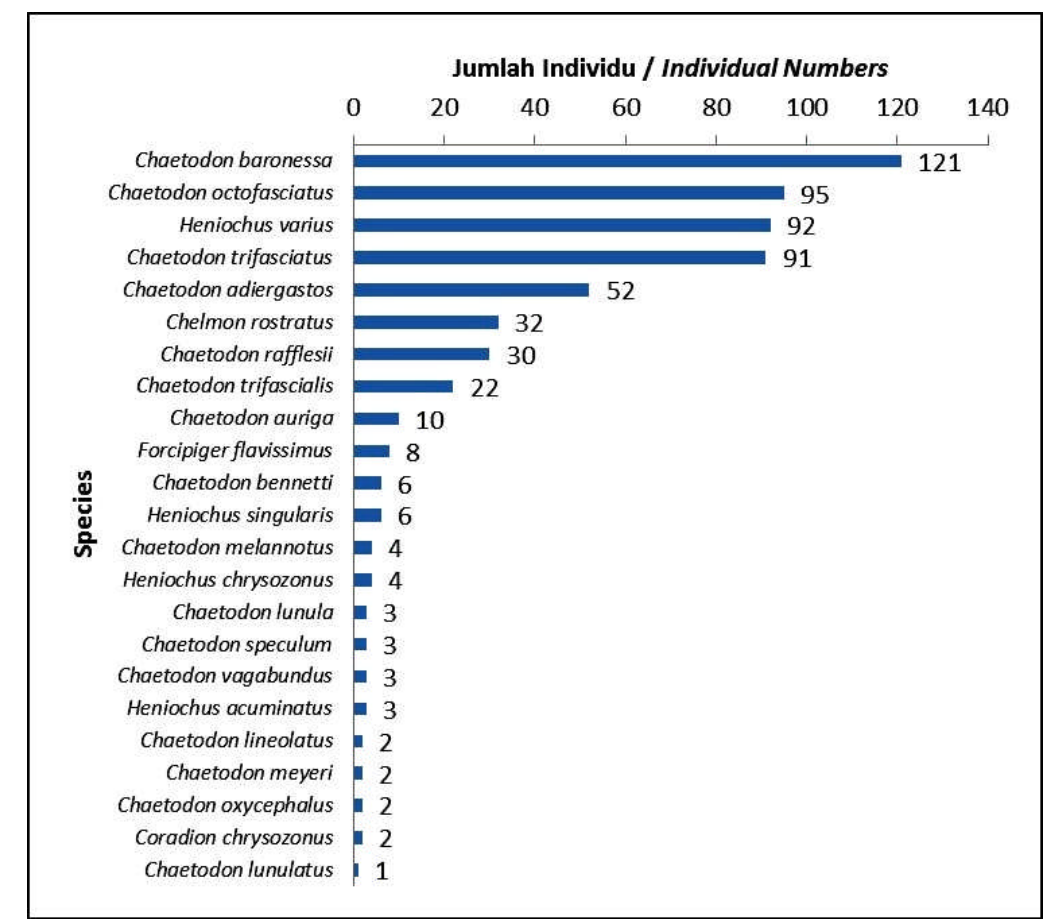

Figure 2. Chaetodontid fishes (family Chaetodontidae) composition based on individual numbers.

\section{Discussion}

The fish species richness presented in all study sites was higher than those in the each respective local sites, where it's especially true for coral reef fishes. The large scale of coral reef areas might have increased the target species that has been found by visual census activities. While habitat complexity may serve more reef fish diversity in spread out geographical gradients (Roberts \& Ormond 1987;
Feary et al., 2007.), the diversity and biomass of target species and indicator species identified in all study sites at unusually low levels, compared to other coral reefs (Hadi et al. 2017; Tuti et al., 2015; 2016 \& 2017). For example, the study of COREMAP-CTI Program in the coral reefs area of Wakatobi waters in 2016 found around 40 to 60 species of 20 families in 15 study sites (Tuti et al., 2016), while Natuna coral reefs had only 41,64 species, in average. The number of species that had been identified in Wakatobi coral 
reefs in 2015 and 2016 ranged from 118 to 129 of total target species and 28 to 30 of indicator species (Tuti et al., 2015 \& 2016); these numbers were higher than those in Natuna coral reefs. The relative stock average of target fishes settled in Wakatobi coral reefs (1.6 ton/ha) was higher than that in Natuna coral reefs ( $0.6 \mathrm{ton} / \mathrm{ha}$ ). One of the similarities between both study areas was only the number of fusilier species (Caesionidae). This study indicated the needs of careful management because the phenomenon trends showed the critical condition of the sustainability of target fish species. Therefore, the entire coral reef ecosystem has to be maintained and managed more seriously in an appropriate way. Otherwise, the coral reef environment sustainability might be out of control and impacted closer to the financial local community capability in that area.

Despite the particular species number, a few greater big fusilier species in Natuna reef waters, especially Caesio spp. and Pterocaesio spp. in addition to Lutjanus bigutattus, $L$. ehrenbergii, and $L$. vittae, might be taken into consideration as specially interest withinside the context of fishery management. These species have been recorded as the important major capturing fish by Research Institute for Marine Fisheries (Suman et al., 2014) in the Republic of Indonesia - Fishery Management Area code 711 in the South China Sea region.

Thel reef fishes in Natuna waters were probably similar to other fish assemblages in the other damaged coral reef areas (Utama et al., 2019) that was mostly presented by small individual herbivores (46.45\%) and a low number of the carnivorous fishes group. Such conditions may be reasonably favorable for implementing sustaining coral reef resilience. It's important that biodiversity of functional groups such as herbivorous fishes are critical substantial needs to provide guarantees for expanded coral reef growings, especially by stabilizing the certain functional fish groups for which they may have to manipulate shifting for biota regimes in terms of coral reef resilience purposes (Thibout et al., 2012).

Herbivorous fishes, such as parrotfishes (Scaridae), surgeonfishes (Acanthuridae), and rabbit fishes (Siganidae), are the most important grazers for coral reef resilience remedies. Therefore, they may considerably play a role of controlling and reducing algae expansion from which they may replace substrates for preparing coral larvae to grow so that new coral recruitment was established on substrates given (Berkepile \& Hay, 2008; Green \& Bellwood, 2009). However, the algae clearing and bio-erosion intensities , to provide more surfaces for reef planula attachment, depend on herbivorous fish composition and their body sizes. Functional fish groups in the inherent characteristics of excavators, scrapers, grazers, and browsers, in which fish species already listed by Obura \& Grimsditch (2009), have differentiation of degrees in effectiveness for the algae clearing. It depends on the body size of the grazers. Usually small grazers are mostly less effective to the resilience process.

The present study found that most small herbivores, such as Scarus spp., Siganus spp., and Acanthurus spp., live in high individual numbers. Within this group, Scarus ghobban was the most active grazer species or scraper. Mostly, scrapers produce less effects on bio-erosion of the surfaces than that by excavators (Obura \& Grimsditch, 2009). Scarus ghobban was abundantly found in the whole phases of ages; however, the juvenile sizes were mostly found in the habitat where the condition was in minor effects of resilience remedies. Meanwhile, the majority of parrotfishes and rabbitfishes considerable as grazers or browsers were rarely found high in both species and individual numbers at the study sites. The dominant rabbitfish was Siganus virgatus. In addition to excavators, Bolbometopon muricatum was the only large body size grazer, ,well known as the most important bioerosion fish (Obura \& Grimsditch, 2009); however, its population size was at a low level in the study area. The other smaller excavators identified in the study sites primarily included Chlorurus bowersi, Chlorurus sordidus, and some Naso spp.

On the other hand, a large number of carnivorous fish species, such as soldierfishes, emperors, sweetlips, snappers, goatfishes, spinecheeks, rudderfishes, trevallies, and barracudas, as well as fusiliersof omnivorous fishes, considerably play important roles in controlling herbivorous fish groups and then indirectly affect the on-going coral reef resilience progresses (Obura \& Grimsditch, 2009; Green \& Bellwood, 2009). However, because the carnivore and omnivore groups are increasingly targeted by fishermen, including for live reef food fish trade, along with herbivore groups they are reasonably favorable for commercial fisheries. Hence, the fisheries sector actually leads to a negative ecological consequence for resilience progression, but not for economical fishery interests (Edrus \& Abrar, 2016). Even with great schooling fenomena of fusiliers seen at the Natuna coral reefs that might seriously be a warning for the coral reef management authority, because the fusiller schooling will be attractive for blasting and muroami fishing (Edrus, 2014). 
When the fusilier colonies in reef waters may be suitable for a fishing activity indicator in regard to alerting the coral reef threats, the butterflyfishes may be decided to be a confirmed indicator of coral health (Pratchett et al., 2013). This study found and indicated that the abundances of butterflyfishes were essential to carry out their community structure status, because it will indicate the coral reef's healthy environments. It was found that some coral reefs in the study sites, such as Buluh Island, Burung Island, Tekul Path Reef, Kumbik Island, Solor Island, and Sededap Island, performed good conditions. Some important butterflyfishes (fam. Chaetodontidae) based on their individual numbers and wide distribution were Chaetodon adiergastos, Chaetodon baronessa, Chaetodon octofasciatus, Chaetodon trifasciatus, Chelmon rostratus, and Heniochus varius. These species were quite widespread in the study sites. Furthermore, butterfly fish species with high individual numbers found in Natuna coral reefs were Chaetodon baronessa and Chaetodon octofasciatus. The species of $C$. baronessa was commonly found on the branching corals and tabulate corals in clear waters, whereas $C$. octofasciatus species was mostly found in shady reef waters (Allen \& Erdmann, 2012; Reese, 1981; Edrus \& Syam, 1998), with most study sites had shown low level horizontal visibility of water body (Table 1). According to Suharti (2012) and Suryanti et al. (2011), the butterflyfishes abundance and diversity have positive correlation to coral percent coverage and water depth. It was suggested that butterflyfishes found in varied abundances among respective study sites were due to differential conditions of coral reefs (Pratchett et al., 2006). According to Crosby and Reese (1996). The best reef health is addressed to high level species diversity of butterflyfishes, as they have been found in 44 species in the Papuan coral reefs, whereas in the Natuna coral reefs there were 23 species only. It indicated that the reef health in Natuna reef waters may be classified as moderate to poor levels.

\section{CONCLUSIONS}

The species number of reef fishes in Natuna reef waters is quite high with 123 species, where their mean relative stock was 0.6 ton/ha. The contribution of the herbivore group as functional supports on coral reef resilience was about $46.45 \%$, the carnivore and planktivore groups as top predators and high commercial fishes were about $18.64 \%$ and $14.28 \%$, respectively, and the corallivorous species as coral obligations and reef health indicators was the rest with about 23 species. The major herbivorous species were Scarus spp. The major carnivorous species were Lutjanus spp. The major omnivorous species were
Caesio cuning and Pterocaesio caerulaurea. Meanwhile, the corallivorous species were dominated by Chaetodon baronessa and $C$. octofasciatus. The results suggested that the species composition were quite prospectively implemented for fisheries, especially for fusiliers and snappers; however, it may not be promised for coral reef resilience. Furthermore, the coral health status was at a moderate level regarding high species numbers of corallivorous butterflyfishes.

\section{REFERENCES}

Allen, G.R., \& Erdmann, M.V. (2012). Reef Fishes of the East Indies. Vol I-III. Perth, Australia: Tropical Reef Research.

Anonymous. (2011). Terumbu karang NTT rusak berat. http://mediapalu.com/? p=8572. Upload July 25, 2011.

Berkepile, D.E., \& Hay, M.E. (2008). Herbivore species richness and feeding complementary affect community structure and function on a coral reef. PNAS 105: 16201-16206. doi:10.1073/pnas. 0801946105.

COREMAP (2007). Study baseline ekologi lokasi Natuna Tahun 2007 (119 pp). A. Manuputti (Ed). Jakarta: CRITC COREMAP II -LIPI.

Crosby, M.P. \& Reese, E.S. (1996). A Manual for Monitoring Coral Reefs With Indicator Species: Butterflyfishes as Indicators of Change on Indo Pacific Reefs. (45 pp.). Silver Spring, MD.: Office of Ocean and Coastal Resource Management, National Oceanic and Atmospheric Administration.

Edinger, E.N., Jompa, J., Limmon, G.V., Widjatmoko, W., \& Risk, M.J. (1998). Reef degradation and coral biodiversity in Indonesia: Effects of land-based pollution, destructive fishing practices and changes over time. Mar. Pollut. Bull. Vol. 36, 617-630. https://doi.org/10.1016/S0025-326X(98) 00047-2.

Edrus, I.N., \& Syam, A.R. (1998). (In Indonesian). Distribution of the Chaetodontirlae in coastal Waters of Ambon Island and their role in determining coral reef condition. By: Isa Nagib EclrusJ. Lit. Perik. Ind, 4(3), 1-10. DOI: http:// dx.doi.org/10.15578/jppi.4.3.1998.1-10.

Edrus, I.N. (2014). Policy Making to Utilize Pots Under Artificial Reef and Payaos Supports in the Rehabilitation Areas of Pari and Pramuka Waters, Seribu Islands J. Kebijak. Perikan. Ind, 6(1): 11- 
22. DOI: http://dx.doi.org/10.15578/ jkpi.6.1.2014.11-22.

Edrus, I.N., \& Abrar, M. (2016). Diversity of reef fish functional groups in terms of coral reef resiliences. Ind.Fish.Res.J. Vol. 22 No. 2,109-122. DOI: http:/ /dx.doi.org/10.15578/ifrj.22.2.2016.109-122.

English, S., Wilkinson, C., \& Baker, V. (1994). Survey manual for tropical marine resources. Townsville, Australia: Australian Institute of Marine Science.

Fauzi, A. (2005). (In Indonesian). Policies for Fisheries and Marine: Issues, Synthesis, and Ideas. (p.185). Jakarta: Gramedia.

Feary, D.A., Almany, G.R., Jones, G.P., \& McCormick, M.I. (2007). Coral degradation and the structure of tropical reef Fish communities. Mar. Ecol. Prog. Ser. 333, 243-248. DOI: 10.3354/meps333243.

Froese, R., \& Pauly, D. Editors. (2014). FishBase. World Wide Web electronic publication. www.fishbase.org, version (04/2014).

Giyanto, Manuputty, A.E.W., Abrar, M., Siringoringo, R.M., Suharti, R.S., Wibowo, K., Edrus, I.N., Arbi,U.Y., Cappenberg, H.A.W., Sihaloho, A.F., Tuti, M.I.Y., \& Anita, D.Z. (2014). (In Indonesian). Coral Reef Monitoring Guidance (77 pp.). Jakarta, Indonesia: Pusat Penelitian Oseanografi-Lembaga Ilmu Pengetahuan Indonesia.

Gratwicke B., \& Speight, M.R. (2005). The relationship between fish species richness, abundance and habitat complexity in a range of shallow tropical marine habitats. Jour. Fish Biol. 66, 650-667. DOI: 10.1111/j.0022-1112.2005.00629.x.

Green, A. L., \& Bellwood, D.R. (2009). Monitoring functional groups of herbivorous reef fishes as indicators of coral reef resilience. A practical guide for coral reef managers in the Asia Pacific region (p. 70). Gland, Switzerland: IUCN working group on Climate Change and Coral Reefs.

Halford, A., Cheal, A.J., Ryan, D.A.J., \& Williams, D.M. (2004). Resilience to large-scale disturbance in coral and fish assemblages on the Great Barrier Reef. Ecology 85, 1892-1905.

Hadi, T.A., Suharsono, Tuti, M.I.Y. , Abrar, M., Sulha, S., Cappenberg, H.A.W., Putra, M.Y. Edrus, I.N. Pramuji, Purnomo, L.H., Rasyidin, A., Hafizt, M., I. Al Hakim, I., Sianturi, R.O., \& Lisdayanti, E.. (2007). (In Indonesian). Reef Health Monitoring and the Other Linkage Ecosystem Buton Islands, Southeast Sulawesi 2017 (p. 98). Jakarta, Indonesia: COREMAP-CTI, P2O-LIPI.

Jones, GP, McCormick, M.I., Srinivasan, M., \& Eagle, J.V. (2004). Coral decline threatens fish biodiversity. Proc. Natl. Acad Sci. U.S. A. 101, 8251-8253. doi: 10.1073/ pnas. 0401277101.

Kuiter, R.H., \& Tonozuka, T. (2001). Pictorial Guide to: Indonesian Reef Fishes. Australia: Zoonetics Publc. Seaford VIC 3198.

Obura, D., \& Grimsditch, G. (2009). Resilience assessment of coral reefs rapid assessment protocol for coral reefs, focusing on coral bleaching and thermal stress (p.71). Gland, Switzerland: IUCN Resilience Science Group Working Paper SeriesNo 5.

Pauly, D., Silvestre, G., \& Smith, I.R. (1989). On development, fisheries and dynamite: a brief review of tropical fisheries management. Natural Resources Modelling 3(3), 307-29. https://s3-uswest-2. amazonaws.com/legacy.seaaroundus/ doc/Researcher+Publications/dpauly/PDF/1989/ Journal+ArticlesOnDevelopmentFisheriesDynamite.pdf

Pet-Soede, C., \& Erdmann, M.V.E. (1998). Blast fishing in SW Sulawesi, Indonesia. NAGA, The ICLARM Quarterly 2(2): 4-9. http:// pubs.iclarm.net/Naga/na_2294.pdf.

Pet-Saode, L., Cesar, H.S.J., \& Pet, J.S. (2000). Economic issues related to blast fishing on Indonesian coral reefs. Jurnal Pesisir dan Lautan, Vol.3 (2), 33-40.https://pdfs.semanticscholar.org/ e0e154f84868fb2d3d182923206d82d932c3862a.pdf

Pratchett, M.S., Wilson, S.K., \& Baird, A.H. (2006). Declines in the abundance of Chaetodon butterflyfishes following extensive coral depletion. Journal of Fish Biology, 69(5), 12691280. https:// doi.org/10.1111/j.10958649.2006.01161.x

Pratchett, M. S., Graham, N. A. J., \& Cole, A.J. (2013). Specialist corallivores dominate butterflyfish assemblages in coral dominated reef habitats. Journal of Fish Biology, 82(4),1177-1191. doi: 10.1111/jfb.12056.

Reese, E. (1981). Predation on corals by fishes of the family Chaetodontidae: implication for conservation and management of coral reef ecosystem. Bulletin of Marine Science. 31(3), 594- 
604. http://docserver.ingentaconnect.com/deliver/ connect/umrsmas/00074977/v31n3/ s11.pdf?expires $=1589999960 \&$ id $=$ 0000\&titleid $=10983$ \& checksum $=3$ B 12 DAB2318 CC57BFD7985E445E0DE86.

Roberts, C.M., \& Ormond, R.F. (1987). Habitat complexity and coral reef Diversity and abundance on Red Sea fringing reefs. Mar. Ecol. Prog. Ser. 41, 1 - 8. Doi:0171-8630/87/0041/0001/\$03.00

Salm, R.V., \& Kenchington, R.A. (1988). The need for management. In: Coral Reef Management Handbook (p. 9). R.A. Kenchington and B.E.T. Hudson (Eds). Jakarta, Indonesia: Unesco Publisher.

Suharti, R. (2012). (In Idonesian). The Relationship between Coral Reef with Chaetodontidae Fish in the Waters of Karang Bongkok, Kepulauan Seribu. Thesis. Indonesia: Universitas Terbuka. http:// repository.ut.ac.id/id/eprint/930

Suman, A., Wudianto, Sumiono, B., Badrudin, Nugroho, D., Merta, G.S., Suwarso, Taufik, M., Amri, K., Kembaren, D., Priyatna, A., Setiaji, E., Prihantara, S., Prihatiningsih, Chodrijah, U., Fauzi, M., Ernawati, T., \& Rahmat, E. (2014). (In Indonesian). Resources of Demersal fish and coral reef fish in Selat Karimata, Laut Natuna dan Laut Cina Selatan (Hal. 65). In: Potention and Utility Level of Fish Resources in the 711-Fishery Management Area (p. 224). Suman, A. , Wudianto, Sumiono, B., Badrudin, \& Nugroho, D. (Eds). Jakarta, Indonesia : Penerbit Ref Graphika.

Suryanti, Supriharyono, \& Indrawan, W. (2011). (In Indonesian) Coral Reef Condition In Regard to Indicator Fishes of Chaetodontidae in the Sambangan Island of Kepulauan Karimun Jawa, Jepara, Center of Java. Buletin Oseanografi Marina.Vol. 1(1), 106 -119. DOI: $10.14710 /$ buloma.v1i1.2988
Thibout, L.M., Connolly, S.R., \& Sweatman, P.A. (2012). Diversity and stability of herbivorous fishes on coral reefs. Ecology 93, 891 - 901. doi: 10.1890/11-1753.1.

Tuti, M.I.Y., Suyarso, Suharti, S.R., Cappenberg, H.A.W., Edrus, I.N., Darmawan, I.W.E., Hadi, T.A., Utama, R.S., Budianto, A., Salatalohi, A., \& Sulha, S. (2015). (In Indonesian). Reef Health Monitoring and the Other Linkage Ecosystem in Wakatobi District, Southeat Sulawesi 2015 (118 pp). Jakarta, Indonesia: COREMAP-CTI, P20-LIPI.

Tuti, M.I.Y., Suyarso, Suharti, S.R., Cappenberg, H.A.W., Edrus, I.N., Darmawan, I.W.E., Hadi, T.A., Utama, R.S., Budianto, A., Salatalohi, A. \& Sulha, S. (2016). (In Indonesian). Reef Health Monitoring and the Other Linkage Ecosystem in Wakatobi District, Southeast Sulawesi 2016 (118 pp). Jakarta, Indonesia: COREMAP-CTI, P20-LIPI.

Tuti, M.I.Y., Suharti, S.R., Cappenberg, H.A.W., Edrus, I.N., Darmawan, I.W.E., Hadi, T.A., Utama, R.S., Budianto, A., Salatalohi, A. \& Sulha, S. (2017). (In Indonesian). Reef Health Monitoring and the Other Linkage Ecosystem in Wakatobi District, Southeast Sulawesi 2017 (119 pp). Jakarta, Indonesia: COREMAP-CTI, P20-LIPI.

Utama, R.S., Edrus, I.N. \& Makatipu, P.C. (2019). (In Indonesian). Reef Fish Community in the Adjacent Waters of Ternate Island. Oseanologi dan Limnologi di Indonesia.4(1), 53 - 69. DOI: 10. 14203/oldi.2019.v4i1.228.

Wilson J.R. \& Green, A.L. (2009). Biological Monitoring Method to assess coral reef Health and Management Effectiveness for Marine Conservation Area Management in Indonesia (46 pp). Jakarta, Indonesia: TNC Report. Indo. Marine Program Versi 1.0, No. 1/09. 
Appendix 1. Individual composition of reef fishes in Natuna reef waters.

\begin{tabular}{|c|c|c|c|c|c|c|c|}
\hline \multirow{2}{*}{ No. } & \multirow{2}{*}{ SPECIES } & \multirow{2}{*}{ FAMILY } & \multirow{2}{*}{$\begin{array}{l}\text { Ind. } \\
\text { No. }\end{array}$} & \multicolumn{4}{|c|}{ COMPOSITION (\%) } \\
\hline & & & & Ind. & Herbivores & Carnivores & Planktivores \\
\hline 1 & Scarus ghobban & Scaridae & 2,182 & 18.64 & 18.64 & & \\
\hline 2 & Caesio cuning & Caesionidae & 1,671 & 14.28 & & & 14.28 \\
\hline 3 & Caesio caerulaurea & Caesionidae & 1,006 & 8.60 & & & 8.60 \\
\hline 4 & Scarus hypselopterus & Scaridae & 749 & 6.40 & 6.40 & & \\
\hline 5 & Chlorurus sordidus & Scaridae & 701 & 5.99 & 5.99 & & \\
\hline 6 & Pterocaesio tessellata & Caesionidae & 444 & 3.79 & & & 3.79 \\
\hline 7 & Scarus niger & Scaridae & 343 & 2.93 & 2.93 & & \\
\hline 8 & Scolopsis ciliatus & Scolopsidae & 336 & 2.87 & & 2.87 & \\
\hline 9 & Ctenochaetus striatus & Acanthuridae & 262 & 2.24 & 2.24 & & \\
\hline 10 & Lutjanus ehrenbergii & Lutjanidae & 223 & 1.91 & & 1.91 & \\
\hline 11 & Lutjanus biguttatus & Lutjanidae & 217 & 1.85 & & 1.85 & \\
\hline 12 & Pterocaesio digramma & Caesionidae & 210 & 1.79 & & & 1.79 \\
\hline 13 & Lutjanus decussatus & Lutjanidae & 183 & 1.56 & & 1.56 & \\
\hline 14 & Siganus virgatus & Siganidae & 166 & 1.42 & 1.42 & & \\
\hline 15 & Lutjanus vitta & Lutjanidae & 153 & 1.31 & & 1.31 & \\
\hline 16 & Scarus flavipectoralis & Scaridae & 143 & 1.22 & 1.22 & & \\
\hline 17 & Caesio lunaris & Caesionidae & 138 & 1,18 & & & 1.18 \\
\hline 18 & Parupeneus barberinus & Mullidae & 136 & 1.16 & & 1.16 & \\
\hline 19 & Epibulus insidiator & Labridae & 115 & 0.98 & & 0.98 & \\
\hline 20 & Cheilinus fasciatus & Labridae & 114 & 0.97 & & 0.97 & \\
\hline 21 & Acanthurus nigricans & Acanthuridae & 103 & 0.88 & 0.88 & & \\
\hline 22 & Parupeneus multifasciatus & Mullidae & 103 & 0.88 & & 0.88 & \\
\hline 23 & Scolopsis margaritifer & Scolopsidae & 103 & 0.88 & & 0.88 & \\
\hline 24 & Chlorurus bowersi & Scaridae & 100 & 0.85 & 0.85 & & \\
\hline 25 & Naso lituratus & Acanthuridae & 98 & 0.84 & 0.84 & & \\
\hline 26 & Hemigymnus melapterus & Labridae & 92 & 0.79 & & 0.79 & \\
\hline 27 & Scarus forsteni & Scaridae & 90 & 0.77 & 0.77 & & \\
\hline 28 & Scarus schlegeli & Scaridae & 88 & 0.75 & 0.75 & & \\
\hline 29 & Pentapodus trivittatus & Nemipteridae & 87 & 0.74 & & 0.74 & \\
\hline 30 & Caesio teres & Caesionidae & 86 & 0.73 & & & 0.73 \\
\hline 31 & Scolopsis bilineatus & Scolopsidae & 83 & 0.71 & & 0.71 & \\
\hline 32 & Upeneus tragula & Mullidae & 69 & 0.59 & & 0.59 & \\
\hline 33 & Scarus dimidiatus & Scaridae & 63 & 0.54 & 0.54 & & \\
\hline 34 & Hemigymnus fasciatus & Labridae & 62 & 0.53 & & 0.53 & \\
\hline 35 & Sargocentron caudimaculatum & Holocentridae & 56 & 0.48 & & 0.48 & \\
\hline 36 & Siganus vulpinus & Siganidae & 48 & 0.41 & 0.41 & & \\
\hline 37 & Siganus corallinus & Siganidae & 46 & 0.39 & 0.39 & & \\
\hline 38 & Kyphosus vaigiensis & Kyphosidae & 42 & 0.36 & & 0.36 & \\
\hline 39 & Scarus scaber & Scaridae & 41 & 0.35 & 0.35 & & \\
\hline 40 & Naso hexacanthus & Acanthuridae & 34 & 0.29 & 0.29 & & \\
\hline 41 & Cephalopholis argus & Serranidae & 31 & 0.26 & & 0.26 & \\
\hline 42 & Zebrasoma scopas & Acanthuridae & 31 & 0.26 & 0.26 & & \\
\hline 43 & Sphyraena flavicauda & Sphyraenidae & 30 & 0.26 & & 0.26 & \\
\hline 44 & Choerodon anchorago & Labridae & 28 & 0.24 & & 0.24 & \\
\hline 45 & Kyphosus cinerascens & Kyphosidae & 28 & 0.24 & & 0.24 & \\
\hline 46 & Myripristis murdjan & Holocentridae & 28 & 0.24 & & 0.24 & \\
\hline 47 & Caranx melampygus & Carangidae & 26 & 0.22 & & 0.22 & \\
\hline 48 & Parupeneus barberinoides & Mullidae & 26 & 0.22 & & 0.22 & \\
\hline 49 & Platax orbicularis & Ephippidae & 24 & 0.21 & & & 0.21 \\
\hline 50 & Monotaxis grandoculis & Lethrinidae & 23 & 0.20 & & 0.20 & \\
\hline 51 & Parupeneus bifasciatus & Mullidae & 22 & 0.19 & & 0.19 & \\
\hline 52 & Parupeneus cyclostomus & Mullidae & 22 & 0.19 & & 0.19 & \\
\hline 53 & Plectorhinchus lessonii & Haemulidae & 21 & 0.18 & & 0.18 & \\
\hline
\end{tabular}




\begin{tabular}{|c|c|c|c|c|c|c|c|}
\hline 54 & Acanthurus mata & Acanthuridae & 20 & 0.17 & 0.17 & & \\
\hline 55 & Cephalopholis boenak & Serranidae & 19 & 0.16 & & 0.16 & \\
\hline 56 & Scarus spinus & Scaridae & 19 & 0.16 & 0.16 & & \\
\hline 57 & Scarus microrhinos & Scaridae & 17 & 0.15 & 0.15 & & \\
\hline 58 & Plectorhinchus chaetodontoides & Haemulidae & 16 & 0.14 & & 0.14 & \\
\hline 59 & Acanthurus leucocheilus & Acanthuridae & 15 & 0.13 & 0.13 & 0.13 & \\
\hline 60 & Cephalopholis cyanostigma & Serranidae & 15 & 0.13 & & 0.13 & \\
\hline 61 & Lutjanus monostigma & Lutjanidae & 14 & 0.12 & & 0.12 & \\
\hline 62 & Pterocaesio trilineata & Caesionidae & 14 & 0.12 & & & 0.12 \\
\hline 63 & Acanthurus olivaceus & Acanthuridae & 13 & 0.11 & 0.11 & & \\
\hline 64 & Cheilinus trilobatus & Labridae & 13 & 0.11 & & 0.11 & \\
\hline 65 & Macolor macularis & Lutjanidae & 13 & 0.11 & & 0.11 & \\
\hline 66 & Oxycheilinus digramma & Labridae & 12 & 0.09 & & 0.10 & \\
\hline 67 & Siganus guttatus & Siganidae & 12 & 0.09 & & 0.09 & \\
\hline 68 & Acanthurus lineatus & Acanthuridae & 10 & 0.09 & 0.09 & & \\
\hline 69 & Lethrinus erythropterus & Lethrinidae & 10 & 0.09 & & 0.09 & \\
\hline 70 & Lutjanus carponotatus & Lutjanidae & 10 & 0.09 & & 0.09 & \\
\hline 71 & Caranx bajad & Carangidae & 9 & 0.05 & & 0.08 & \\
\hline 72 & Cetoscarus bicolor & Scaridae & 9 & 0.05 & 0.08 & & \\
\hline 73 & Epinephelus fasciatus & Serranidae & 9 & 0.05 & & 0.08 & \\
\hline 74 & Lutjanus quinqueleneatus & Lutjanidae & 9 & 0.05 & & 0.08 & \\
\hline 75 & Siganus puellus & Siganidae & 9 & 0.05 & 0.08 & & \\
\hline 76 & Pomacanthus sexstriatus & Pomacanthidae & 8 & 0.07 & & 0.07 & \\
\hline 77 & Ctenochaetus binotatus & Acanthuridae & 7 & 0.05 & 0.06 & & \\
\hline 78 & Lutjanus bohar & Lutjanidae & 7 & 0.05 & & 0.06 & \\
\hline 79 & Zebrasoma veliferum & Acanthuridae & 7 & 0.05 & 0.06 & & \\
\hline 80 & Oxycheilinus celebicus & Labridae & 6 & 0.05 & & 0.05 & \\
\hline 81 & Siganus argenteus & Siganidae & 6 & 0.05 & 0.05 & & \\
\hline 82 & Cephalopholis urodeta & Serranidae & 5 & 0.04 & & 0.04 & \\
\hline 83 & Aethaloperca rogaa & Serranidae & 4 & 0.03 & & 0.03 & \\
\hline 84 & Bolbometopon muricatum & Scaridae & 4 & 0.03 & 0.03 & & \\
\hline 85 & Plectropomus leopardus & Serranidae & 4 & 0.03 & & 0.03 & \\
\hline 86 & Scarus tricolor & Scaridae & 4 & 0.03 & 0.03 & & \\
\hline 87 & Plectropomus aerolatus & Serranidae & 3 & 0.03 & & 0,03 & \\
\hline 88 & Scolopsis affinis & Scolopsidae & 3 & 0.03 & & 0.03 & \\
\hline 89 & Siganus canaliculatus & Siganidae & 3 & 0.03 & 0.03 & & \\
\hline 90 & Acanthurus triostegus & Acanthuridae & 2 & 0.02 & 0.02 & & \\
\hline 91 & Cheilinus undulatus & Labridae & 2 & 0.02 & & 0.02 & \\
\hline 92 & Diagramma pictum & Haemulidae & 2 & 0.02 & & 0.02 & \\
\hline 93 & Lethrinus harak & Lethrinidae & 2 & 0.02 & & 0.02 & \\
\hline 94 & Lethrinus obsoletus & Lethrinidae & 2 & 0.02 & & 0.02 & \\
\hline 95 & Mulloidichthys vanicolensis & Mullidae & 2 & 0.02 & & 0.02 & \\
\hline 96 & Naso caeruleacaudus & Acanthuridae & 2 & 0.02 & 0.02 & & \\
\hline 97 & Pentapodus caninus & Nemipteridae & 2 & 0.02 & & 0.02 & \\
\hline 98 & Siganus spinus & Siganidae & 2 & 0.02 & 0.02 & & \\
\hline 99 & Platax teira & Ephippidae & 1 & 0.01 & & & 0.01 \\
\hline \multirow[t]{2}{*}{100} & Pomacanthus imperator & Pomacanthidae & 1 & 0.01 & & 0.01 & \\
\hline & Total & & & & 46.45 & 22.97 & 30.71 \\
\hline
\end{tabular}


Appendix 2. Composition of reef fishes based on biomass ranks

\begin{tabular}{|c|c|c|c|c|}
\hline No & SPECIES & FAMILIES & $\begin{array}{c}\text { BIOMASS } \\
\text { (Gram) }\end{array}$ & $\begin{array}{c}\text { PERCENT } \\
(\%)\end{array}$ \\
\hline 1 & Caesio cuning & Caesionidae & $257,334.8$ & 15.229 \\
\hline 2 & Caesio caerulaurea & Caesionidae & $204,119.2$ & 12.080 \\
\hline 3 & Scarus ghobban & Scaridae & $177,214.8$ & 10.488 \\
\hline 4 & Chlorurus sordidus & Scaridae & $95,012.5$ & 5.623 \\
\hline 5 & Naso lituratus & Acanthuridae & $57,093.6$ & 3.379 \\
\hline 6 & Scarus niger & Scaridae & $50,778.9$ & 3.005 \\
\hline 7 & Pterocaesio tessellata & Caesionidae & $38,000.6$ & 2.249 \\
\hline 8 & Ctenochaetus striatus & Acanthuridae & $35,886.0$ & 2.124 \\
\hline 9 & Lutjanus decussatus & Lutjanidae & $33,509.0$ & 1.983 \\
\hline 10 & Scarus hypselopterus & Scaridae & $29,069.7$ & 1.720 \\
\hline 11 & Pterocaesio digramma & Caesionidae & $26,774.8$ & 1.585 \\
\hline 12 & Scarus flavipectoralis & Scaridae & $26,247.7$ & 1.553 \\
\hline 13 & Lutjanus biguttatus & Lutjanidae & $24,000.6$ & 1,420 \\
\hline 14 & Lutjanus vitta & Lutjanidae & $23,173.7$ & 1,371 \\
\hline 15 & Caesio lunaris & Caesionidae & $23,153.6$ & 1.370 \\
\hline 16 & Lutjanus ehrenbergii & Lutjanidae & $22,805.8$ & 1.350 \\
\hline 17 & Scarus forsteni & Scaridae & $22,047.5$ & 1.305 \\
\hline 18 & Siganus virgatus & Siganidae & $21,659.5$ & 1.282 \\
\hline 19 & Bolbometopon muricatum & Scaridae & $21,008.7$ & 1.243 \\
\hline 20 & Platax orbicularis & Ephippidae & $20,601.3$ & 1.219 \\
\hline 21 & Plectorhinchus chaetodontoides & Haemulidae & $19,343.9$ & 1.145 \\
\hline 22 & Scolopsis margaritifer & Scolopsidae & $18,717.3$ & 1.108 \\
\hline 23 & Scarus schlegeli & Scaridae & $17,903.7$ & 1.060 \\
\hline 24 & Kyphosus vaigiensis & Kyphosidae & $16,378.5$ & 0.969 \\
\hline 25 & Plectorhinchus lessonii & Haemulidae & $16,168.0$ & 0.957 \\
\hline 26 & Parupeneus barberinus & Mullidae & 15985.0 & 0.946 \\
\hline 27 & Monotaxis grandoculis & Lethrinidae & $15,961.5$ & 0.945 \\
\hline 28 & Hemigymnus melapterus & Labridae & $15,920.8$ & 0.942 \\
\hline 29 & Scolopsis ciliatus & Scolopsidae & $15,541.2$ & 0.920 \\
\hline 30 & Acanthurus mata & Acanthuridae & $14,782.6$ & 0.875 \\
\hline 31 & Naso hexacanthus & Acanthuridae & $13,001.2$ & 0.769 \\
\hline 32 & Siganus corallinus & Siganidae & $12,786.2$ & 0.757 \\
\hline 33 & Cheilinus fasciatus & Labridae & $12,680.5$ & 0.750 \\
\hline 34 & Caranx melampygus & Carangidae & $12,220.4$ & 0.723 \\
\hline 35 & Epibulus insidiator & Labridae & $12,186.0$ & 0.721 \\
\hline 36 & Parupeneus multifasciatus & Mullidae & $12,083.3$ & 0.715 \\
\hline 37 & Scarus microrhinos & Scaridae & $10,709.6$ & 0.634 \\
\hline 38 & Sargocentron caudimaculatum & Holocentridae & 10703.5 & 0.633 \\
\hline 39 & Kyphosus cinerascens & Kyphosidae & 10652.0 & 0.630 \\
\hline 40 & Scolopsis bilineatus & Scolopsidae & $10,627.7$ & 0.629 \\
\hline 41 & Cephalopholis argus & Serranidae & $9,648.2$ & 0.571 \\
\hline 42 & Hemigymnus fasciatus & Labridae & $9,567.9$ & 0.566 \\
\hline 43 & Scarus spinus & Scaridae & $9,414.8$ & 0.557 \\
\hline 44 & Acanthurus leucocheilus & Acanthuridae & $8,996.2$ & 0.532 \\
\hline 45 & Caesio teres & Caesionidae & $8,238.8$ & 0.488 \\
\hline 46 & Chlorurus bowersi & Scaridae & $7,845.9$ & 0.464 \\
\hline 47 & Siganus vulpinus & Siganidae & $7,793.7$ & 0.461 \\
\hline 48 & Lethrinus erythropterus & Lethrinidae & $7,792.0$ & 0.461 \\
\hline 49 & Pentapodus trivittatus & Nemipteridae & $7,453.9$ & 0.441 \\
\hline 50 & Myripristis murdjan & Holocentridae & $7,312.0$ & 0.433 \\
\hline 51 & Acanthurus nigricans & Acanthuridae & $6,379.7$ & 0.378 \\
\hline 52 & Parupeneus bifasciatus & Mullidae & $6,227.8$ & 0.369 \\
\hline 53 & Scarus scaber & Scaridae & $5,694.4$ & 0.337 \\
\hline 54 & Choerodon anchorago & Labridae & $5,269.5$ & 0.312 \\
\hline
\end{tabular}




\begin{tabular}{|c|c|c|c|c|}
\hline 55 & Lutjanus monostigma & Lutjanidae & $5,058.0$ & 0.299 \\
\hline 56 & Zebrasoma scopas & Acanthuridae & $4,966.5$ & 0.294 \\
\hline 57 & Pomacanthus sexstriatus & Pomacanthidae & $4,848.9$ & 0.287 \\
\hline 58 & Parupeneus cyclostomus & Mullidae & $4,744.7$ & 0.281 \\
\hline 59 & Acanthurus olivaceus & Acanthuridae & $4,479.3$ & 0.265 \\
\hline 60 & Cetoscarus bicolor & Scaridae & $4,410.8$ & 0.261 \\
\hline 61 & Siganus guttatus & Siganidae & $4,022.6$ & 0.238 \\
\hline 62 & Cephalopholis cyanostigma & Serranidae & $3,883.9$ & 0.230 \\
\hline 63 & Lutjanus carponotatus & Lutjanidae & $3,859.5$ & 0.228 \\
\hline 64 & Upeneus tragula & Mullidae & $3,519.2$ & 0.208 \\
\hline 65 & Sphyraena flavicauda & Sphyraenidae & $3,353.0$ & 0.198 \\
\hline 66 & Scarus dimidiatus & Scaridae & $3,274.2$ & 0.194 \\
\hline 67 & Macolor macularis & Lutjanidae & $3,233.2$ & 0.191 \\
\hline 68 & Caranx bajad & Carangidae & $2,589.2$ & 0.153 \\
\hline 69 & Parupeneus barberinoides & Mullidae & $2,524.1$ & 0.149 \\
\hline 70 & Plectropomus leopardus & Serranidae & $2,286.4$ & 0.135 \\
\hline 71 & Siganus puellus & Siganidae & $2,241.1$ & 0.133 \\
\hline 72 & Scarus tricolor & Scaridae & $2,227.6$ & 0.132 \\
\hline 73 & Acanthurus lineatus & Acanthuridae & $1,886.8$ & 0.112 \\
\hline 74 & Aethaloperca rogaa & Serranidae & $1,747.7$ & 0.103 \\
\hline 75 & Lutjanus quinqueleneatus & Lutjanidae & $1,656.6$ & 0.098 \\
\hline 76 & Naso caeruleacaudus & Acanthuridae & 1397.9 & 0.083 \\
\hline 77 & Lethrinus obsoletus & Lethrinidae & $1,364.1$ & 0.081 \\
\hline 78 & Lutjanus bohar & Lutjanidae & $1,292.1$ & 0.076 \\
\hline 79 & Oxycheilinus digramma & Labridae & 1289.5 & 0.076 \\
\hline 80 & Pomacanthus imperator & Pomacanthidae & $1,192.1$ & 0.071 \\
\hline 81 & Cheilinus trilobatus & Labridae & $1,188.3$ & 0.070 \\
\hline 82 & Epinephelus fasciatus & Serranidae & $1,168.9$ & 0.069 \\
\hline 83 & Diagramma pictum & Haemulidae & 875.0 & 0.052 \\
\hline 84 & Siganus argenteus & Siganidae & 814.2 & 0.048 \\
\hline 85 & Zebrasoma veliferum & Acanthuridae & 758.4 & 0.045 \\
\hline 86 & Ctenochaetus binotatus & Acanthuridae & 710.9 & 0.042 \\
\hline 87 & Cephalopholis boenak & Serranidae & 707.0 & 0.042 \\
\hline 88 & Plectropomus aerolatus & Serranidae & 633.4 & 0.037 \\
\hline 89 & Oxycheilinus celebicus & Labridae & 624.1 & 0.037 \\
\hline 90 & Pterocaesio trilineata & Caesionidae & 517.1 & 0.031 \\
\hline 91 & Mulloidichthys vanicolensis & Mullidae & 456.9 & 0.027 \\
\hline 92 & Siganus canaliculatus & Siganidae & 453.4 & 0.027 \\
\hline 93 & Cephalopholis urodeta & Serranidae & 427.9 & 0.025 \\
\hline 94 & Lethrinus harak & Lethrinidae & 316.1 & 0.019 \\
\hline 95 & Siganus spinus & Siganidae & 286.5 & 0.017 \\
\hline 96 & Acanthurus triostegus & Acanthuridae & 279.4 & 0.017 \\
\hline 97 & Platax teira & Ephippidae & 234.8 & 0.014 \\
\hline 98 & Scolopsis affinis & Scolopsidae & 204.3 & 0.012 \\
\hline 99 & Cheilinus undulatus & Labridae & 195.4 & 0.012 \\
\hline 100 & Pentapodus caninus & Nemipteridae & 46.4 & 0.003 \\
\hline
\end{tabular}

